\title{
Role of mTOR Signaling in Tumor Microenvironment: An Overview
}

\author{
Fabiana Conciatori ${ }^{1}$, Chiara Bazzichetto ${ }^{1,2}$, Italia Falcone ${ }^{1}$, Sara Pilotto ${ }^{3}$, Emilio Bria ${ }^{4}$, \\ Francesco Cognetti ${ }^{1}$, Michele Milella ${ }^{1}$ and Ludovica Ciuffreda ${ }^{1, *}$ \\ 1 Medical Oncology 1, IRCCS Regina Elena National Cancer Institute, Rome 00144, Italy; \\ fabiana.conciatori@ifo.gov.it (F.C.); chiara.bazzichetto@ifo.gov.it (C.B.); italia.falcone@ifo.gov.it (I.F.); \\ francesco.cognetti@ifo.gov.it (F.C.); michele.milella@ifo.gov.it (M.M.) \\ 2 Department of Molecular Medicine, University of Rome, La Sapienza, Rome 00185, Italy \\ 3 Department Medical Oncology Unit, Azienda Ospedaliera Universitaria Integrata, University of Verona, \\ Verona 37100, Italy; sara.pilotto.85@gmail.com \\ 4 Medical Oncology, Fondazione Policlinico Universitario “A. Gemelli" IRCCS Università Cattolica del Sacro \\ Cuore, Rome 00168, Italy; emilio.bria@unicat.it \\ * Correspondence: ludovica.ciuffreda@ifo.gov.it; Tel.: +39-06-5266-5185
}

Received: 11 July 2018; Accepted: 15 August 2018; Published: 19 August 2018

\begin{abstract}
The mammalian target of rapamycin (mTOR) pathway regulates major processes by integrating a variety of exogenous cues, including diverse environmental inputs in the tumor microenvironment (TME). In recent years, it has been well recognized that cancer cells co-exist and co-evolve with their TME, which is often involved in drug resistance. The mTOR pathway modulates the interactions between the stroma and the tumor, thereby affecting both the tumor immunity and angiogenesis. The activation of mTOR signaling is associated with these pro-oncogenic cellular processes, making mTOR a promising target for new combination therapies. This review highlights the role of mTOR signaling in the characterization and the activity of the TME's elements and their implications in cancer immunotherapy.
\end{abstract}

Keywords: mTOR; tumor microenvironment; angiogenesis; immunotherapy

\section{Introduction}

The mammalian target of rapamycin (mTOR) forms two functionally and structurally distinct multi-component complexes, named mTOR complex 1 (mTORC1) and mTOR complex 2 (mTORC2). These two complexes regulate several physiological processes, such as protein synthesis, biosynthesis of macromolecules, cytoskeleton remodeling, angiogenesis, homeostasis, survival, metabolism, autophagy, and response to stress [1]. Because of its key role in cell growth and differentiation, its deregulation is implicated in pathological conditions including neoplastic transformation and progression, such as in breast, gastrointestinal, liver, and prostate cancers [2].

Moreover, the mTOR pathway is involved in the differentiation, function, and metabolic regulation of adaptive/innate immune cells, as demonstrated by the use of rapamycin in clinical practice as an immune suppressant in organ transplant patients. Indeed, mTOR may regulate the activity of immune cells, such as macrophages and $\mathrm{T}$ cells, by regulating the expression of the inflammatory factors, such as cytokines/chemokines (i.e., interleukin (IL)-10, transforming growth factor (TGF)- $\beta$ ) and/or membrane receptors (i.e., Cytotoxic T-Lymphocyte protein 4 (CTLA-4) and Programmed Death 1 (PD-1)) [3]. The immune cells, recruited in the tumor microenvironment (TME) by the cytokines/chemokines-cytokines/chemokines receptor interactions, could exert the anti-tumor functions or promote cancer cells' growth. Thus, inflammation plays a central role in the tumor dynamic and represents one of the hallmarks of cancer [4]. 
Along with the immune system, tumor vasculature is a key component of TME and can influence the tumor behavior and drug treatment; $\mathrm{mTOR}$ is involved in the regulation of tumor-related vascular formation, through the promotion of angiogenesis [5]. One of the most prominent effects of mTOR under a hypoxic condition is the translation of hypoxia-inducible factor (HIF) 1-2. The HIF transcription factors lead to the expression of the hypoxic stress response genes, including angiogenic growth factors such as vascular endothelial growth factor (VEGF), TGF- $\alpha$, and platelet-derived growth factor $\beta$ (PDGF- $\beta$ ) [6].

The mTOR-mediated cellular metabolism is implicated in the cancer cells'-TME interactions during the tumor progression and drug resistance, suggesting that phosphoinositide 3-kinase (PI3K)-/protein kinase B (AKT)-/mTOR-blockade may have the dual benefit of reducing the cells' proliferation, migration, and survival, and enhancing the tumor immunosurveillance through both the downregulation of the immunosuppressive pathways and the activation of anti-tumor immune activities.

In this review, we describe the role of mTOR in tumor and non-tumor cells in order to better analyze the mechanisms of cancer progression and metastasis as well as drug resistance development.

\section{2. mTOR Signaling}

mTOR is an evolutionarily conserved serine/threonine kinase belonging to the PI3K-related kinase family, which integrates a variety of exogenous cues to coordinate several cellular processes, including cell growth and metabolism (Figure 1) [2,7,8].

mTOR forms two functional multiprotein complexes, mTORC1 and mTORC2, which are characterized by the different binding partners that confer distinguishing functions upon them. mTORC1 includes mTOR, raptor, proline-rich AKT substrate 40 (PRAS40), DEP domain-containing mTOR interacting protein (DEPTOR), mammalian lethal with sec13 protein 8 (mLST8), Rac1, GRp58, Tel2-interacting protein 1 (Tti1) and Telomere maintenance 2 (Tel2), while mTORC2 includes rictor, mammalian stress-activated protein kinase interacting protein 1 (mSIN1), protein observed with rictor (Protor) 1/2, proline-rich protein 5 (PRR5), and heat shock protein 70 (Hsp70), in addition to mTOR, DEPTOR, mLST8, Rac1, GRp58, and Tti1 and Tel2 [1]. In both complexes, the mTOR kinase acts as the central catalytic component, whereas the scaffolding protein mLST8, the regulatory subunit DEPTOR, and Tti1/Tel2 act as important regulators of assembly and stability. Furthermore, each complex is composed of specific components that contribute to complex regulation, substrate specificity, and subcellular localization [1].

mTORC1 is rapamycin-sensitive and its main targets are the proteins involved in mRNA translation, including the $\mathrm{p} 70^{S 6 K 1}$ and $4 \mathrm{EBP}-1$. Conversely, mTORC2 is insensitive to rapamycin and the promotes phosphorylation of the hydrophobic motif of protein kinase B (AKT), serum and glucocorticoid kinase (SGK), and protein kinase C (PKC) [9]. The mTORC1 activity depends on diverse positive signals, such as energy levels, oxygen, amino acids, or growth factors, and regulates several processes required for cell growth and metabolism, including ribosomal biogenesis, protein translation, and autophagy. $\mathrm{mTORC} 2$ has been characterized as a downstream effector of the insulin/insulin growth factor (IGF)-1 signaling pathway and it is involved in the regulation of proliferation, survival, cytoskeletal remodeling, and cell migration [9-11]. In response to the insulin or growth factors, mTORC1 is mainly activated by PI3K/AKT signaling [12]; similarly, PI3K is also a key modulator of mTORC2, by promoting the binding of mTORC2 to ribosome [13]. PI3K is activated by receptor tyrosine kinases, G protein-coupled receptors, and RAS, and it acts as a kinase on the lipid second messenger phosphatidylinositol 4,5-bisphosphate (PIP2) to produce phosphatidylinositol 3,4,5-trisphosphate (PIP3), which recruits the phosphoinositide-dependent kinase-1 (PDK1) and AKT to the plasma membrane and thus activating the mTOR signaling [14]. Phosphatase and tensin homolog on chromosome 10 (PTEN) is a classical tumor suppressor and it acts as a phosphatase, by dephosphorylating PIP3 to PIP2 and thus reversing the action of PI3K and its downstream functions $[15,16]$. 


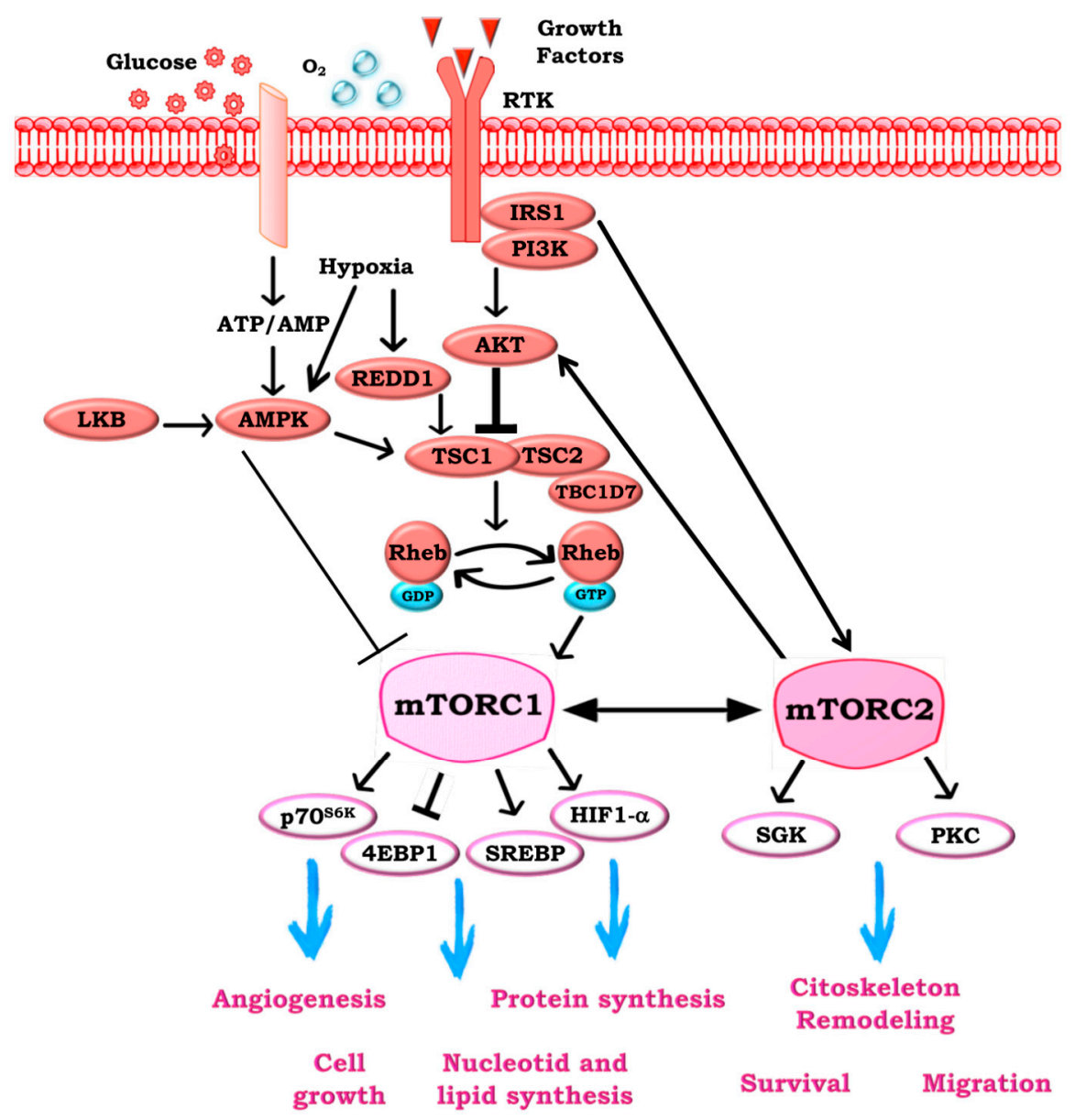

Figure 1. The mammalian target of rapamycin (mTOR) pathway. mTOR signaling is activated by extracellular signals like growth factors, nutrient, and oxygen levels via the phosphoinositide 3-kinase (PI3K)/protein kinase B (AKT) pathways. Extracellular signals may both inhibit the tuberous sclerosis complexes 1-2 (TSC1-2) to promote the accumulation of RAS homolog enriched in brain (Rheb)-GTP and the subsequent activation of mTOR complex 1 (mTORC1), and activate TSC1-2 complex to block mTORC1 by Rheb. Activation of $5^{\prime}$-AMP activated protein kinase $\beta$ (AMPK- $\beta$ ) by low levels of energy results in direct phosphorylation and activation of the TSC1-2 complex. mTOR complex 1 (mTORC1) activation leads to the phosphorylation and activation of mTORC1 effector proteins ribosomal protein S6 kinase $\left(\mathrm{p}^{\mathrm{S}} \mathrm{S}^{\mathrm{KK} 1}\right.$ ) and 4E-Binding Protein 1 (4EBP-1), thus resulting in initiation of specific cap-dependent translation events. Then, mTORC1 regulates cell growth and protein translation through $\mathrm{p} 70^{\mathrm{S} 6 \mathrm{~K} 1}$ and $4 \mathrm{EBP}-1$, as well as lipid synthesis through SREBP1, while angiogenesis through hypoxia-inducible factor (HIF)-1. The function and activation of mTORC2 is less well understood. It is thought to be activated by growth factors through the PI3K pathway and mTORC1. mTORC2 influences the cytoskeletal organization survival and migration.

Because of the key role of mTOR signaling in regulating these fundamental biological processes, the deregulation of the PI3K-AKT-mTOR pathway is tightly connected to cancer initiation and progression, and several biological investigations have focused on targeting this pathway in cancer cells, also within therapeutic combinations [1]. Interestingly, recent evidence shows that treatment with PI3K-AKT-mTOR signaling inhibitors not only affects the tumor progression, but also tumor immunosurveillance within the TME [17]. 


\section{Tumor Microenvironment}

TME is composed of the stroma and its components, different cells types, and paracrine factors (Figure 2) [18]. Mounting evidence suggests the involvement of TME in cancer progression and drug resistance; indeed, in physiological conditions, the stroma acts as a physical barrier, whereas, during carcinogenesis, the presence of tumor cells induce changes that convert the adjacent TME into a pathological entity $[18,19]$.

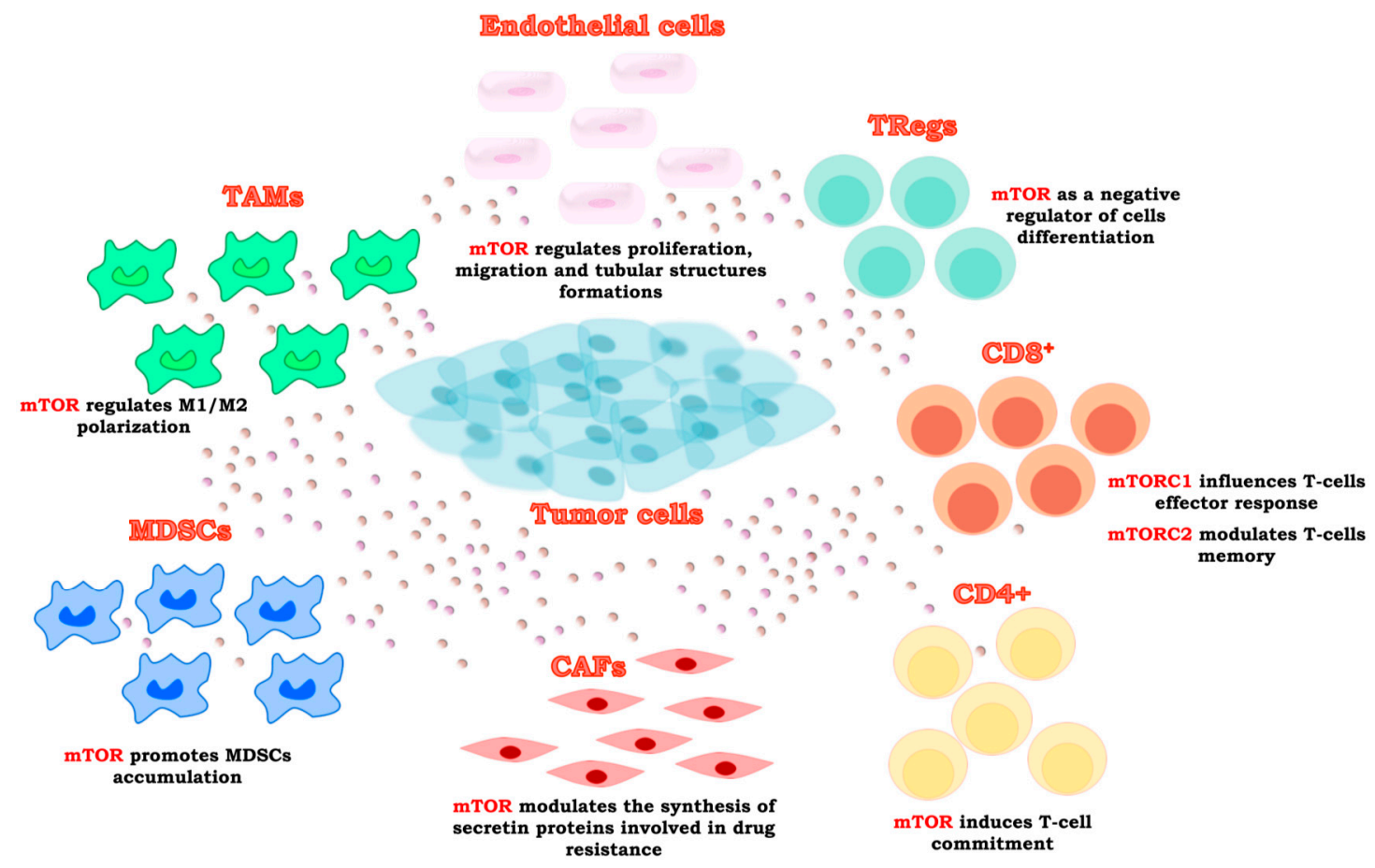

Figure 2. mTOR in characterization and the activity of the tumor microenvironment (TME) elements. mTOR signaling is involved in the modulation of several environmental inputs in TME, mainly composed by regulatory $\mathrm{T}$ cells (Treg), $\mathrm{CD}^{+}$and $\mathrm{CD} 4^{+}$lympohocytes, myeloid-derived suppressor cells (MDSCs), tumor-associated macrophages (TAMs), endothelial cells, and fibroblasts.

Several cell types contribute to the characterization of TME, including cancer and non-cancer cells [20]. Non-malignant components consist of cancer-associated fibroblasts (CAF), myeloid-derived suppressor cells (MDSCs), tumor-associated macrophages (TAM), and regulatory T cells (Treg); they all have a dynamic and tumor-promoting function during the carcinogenesis process [21,22]. CAFs are the major components of cancer stroma and promote tumorigenesis by both remodeling the extracellular matrix (ECM) and secreting cytokines [20]. The MDSCs are myeloid cells, involved in the inhibition of immune cells by releasing IL-10 and in the polarization of TAM towards a tumor-promoting phenotype [20]. Indeed, the TAMs usually display pro-tumorigenic properties and they are the major contributor to tumor angiogenesis [23]. The TAMs represent the prominent leukocytic infiltrate component in cancers and can comprise up to $50 \%$ of the cell tumor mass [24]. The cytokines in the TME directly regulate the phenotype switching of macrophages into M1 and M2 polarization, thus leading to the acquisition of distinct functional features; the M1 macrophages predominantly secrete pro-inflammatory mediators, whereas the M2 secrete the anti-inflammatory ones [25]. Numerous evidence suggest that infiltrating the macrophages switches their phenotype from the anti-tumoral M1 to pro-tumoral M2 during cancer progression, even if the TAMs are the unique polarized macrophages that express both M1 and M2 marker genes [25]. Tregs exert their suppressive activity via cell-to-cell contact (i.e., PD-1 and CTLA-4) or via the expression of soluble factors, such as TGF- $\beta$ and IL-10 [26]. 
The ECM consists not only of a physical scaffold for TAM cells (fibrous and matricellular proteins and glycosaminoglycans), but also of the growth factors, cytokines, and hormones secreted by the stromal and tumor cells. ECM is characterized by biochemical properties specific for each tissue, and may be involved in overcoming the host's immune surveillance [18,27-29].

In TME, the complex and dynamic network of cytokines, chemokines, and growth factors drive the inter- and intra-cellular communication that may modulate tumor/stroma interaction, including immune responses; indeed, the chemokines-chemokine receptors interactions recruit different immune cells into the TME and they regulate the tumor immune responses in a spatiotemporal regulated manner [30].

The cytokines are low-molecular-weight proteins, released by cancer, immune cells, and stromal cells, such as fibroblasts and endothelial cells, in order to regulate the cell proliferation, survival, migration, and death [31]. The chemokines are a type of cytokine with chemo-attractant properties and are divided in four subfamilies (C, CC, CXC, and CX3C), based on their primary structure and function; all have the main cysteine residues in their N-terminal regions [32]. The data obtained in our laboratories have suggested that the hyperactivation of the PI3K-AKT-mTOR pathway is involved in the up-regulation of specific cyto- and chemo-kines expression (i.e., IL-8 and VEGF), thus directly affecting the TME components $[33,34]$. De la Iglesia, et al. demonstrated that in PTEN-loss glioblastoma, the unphosphorylated signal transducer and activator of Signal transducer and activator of transcription 3 (STAT3), which transcriptionally represses IL-8, does not bind the IL-8 promoter, thus leading to an increased transcription and expression of IL-8 gene; in this way, IL-8 promotes the glioblastoma cell proliferation and invasiveness only in a genetic PTEN-loss context [35]. This relationship between PTEN-loss and a selective upregulation of IL-8 signaling has also been demonstrated in prostate carcinoma [36].

\section{Immunoregulatory Functions of mTOR}

Recent studies have established an important role for mTOR in the modulation of both innate and adaptive immunity, integrating different environmental inputs within the TME. Indeed, mTOR is involved in the regulation of many immune cellular functions promoting differentiation, activation of T cells, TAMs, and antigen-presenting cells (Figure 2) [37,38]. The effects of the mTOR complexes' activation in the TME elements are summarized in Table 1.

Table 1. Role of mammalian target of rapamycin (mTOR) complexes in tumor microenvironment (TME) elements. TAM—tumor-associated macrophages (TAM); MDSC—-myeloid-derived suppressor cells; CAF—cancer-associated fibroblasts; IL—interleukin; mTORC1—mTOR complex 1 ; $\downarrow$ indicates a decrease of activity; $\uparrow$ indicates an increase of activity.

\begin{tabular}{cccc}
\hline Element of TME. & mTORC1/2 Modulation & Effects of Modulation & References \\
\hline \multirow{2}{*}{ CD8 ${ }^{+}$} & $\downarrow$ mTORC1 & $\begin{array}{c}\downarrow \text { Effector } \\
\uparrow \text { Memory }\end{array}$ & {$[39,40]$} \\
\cline { 2 - 4 } CD4 & $\downarrow$ mTORC2 & $\downarrow$ Memory & {$[39]$} \\
\hline \multirow{2}{*}{ Treg } & $\uparrow$ mTORC1/2 & $\begin{array}{c}\uparrow \text { Th1, 2, 17 } \\
\text { differentiation }\end{array}$ & {$[41-43]$} \\
\hline TAM & $\uparrow$ mTORC1 & $\begin{array}{c}\uparrow \text { Differentiation in } \\
\text { effector-like T cells }\end{array}$ & {$[44]$} \\
\hline MDSC & $\uparrow$ mTORC2 & $\downarrow$ Differentiation & {$[45,46]$} \\
\hline Endothelial cells & $\uparrow$ mTORC1/2 & $\uparrow$ M2 polarization & {$[47,48]$} \\
\hline CAF & $\uparrow \uparrow$ mTORC1 & Variable effects & {$[49-51]$} \\
\hline mTORC1 & $\uparrow$ Proliferation & {$[52,53]$} \\
\hline mTORC1 & $\downarrow$ IL-6 secretion & {$[54]$} \\
\hline
\end{tabular}


It is actually known that the PI3K/mTOR inhibitors have an important immunomodulatory impact on the tumor microenvironment and angiogenesis. The modulation in the number and/or function of the specific TME cells involved in tumor progression is often associated with a better outcome in cancer therapy, and for this reason, the selective inhibition of the PI3K/mTOR axis correlates not only with the efficacy in leukemias, but also improves the immunotherapy in different solid cancer $[27,55]$. Recent studies showed that the inhibition of different hub of PI3K/mTOR pathways impacts the different TME components (Table 2).

Table 2. mTOR-axis inhibitors and potential therapeutic benefit. PI3K-phosphoinositide 3-kinase; Treg-regulatory T cells.

\begin{tabular}{|c|c|c|c|c|}
\hline Drug(s) & $\begin{array}{l}\text { Target Cell } \\
\text { Population }\end{array}$ & $\begin{array}{l}\text { Functional } \\
\text { Implication }\end{array}$ & $\begin{array}{c}\text { Potential } \\
\text { Therapeutic } \\
\text { Benefit }\end{array}$ & References \\
\hline $\begin{array}{l}\mathrm{mTOR} / \mathrm{p} 110 \beta / \text { pan-PI3K } \\
\text { inhibitors }\end{array}$ & $\mathrm{CD}^{+}$ & $\begin{array}{l}\uparrow \mathrm{CD}^{+} \text {infiltration } \\
\text { in tumor }\end{array}$ & $\begin{array}{c}\uparrow \text { Significant } \\
\text { survival benefit }\end{array}$ & {$[39,56,57]$} \\
\hline mTORC1 inhibitor & $\mathrm{CD}^{+}$ & $\downarrow$ number of $\mathrm{CD}^{+}$ & $\begin{array}{c}\uparrow \text { Significant } \\
\text { survival benefit }\end{array}$ & {$[58]$} \\
\hline $\begin{array}{c}\mathrm{mTOR} / \text { pan-AKT } \\
\text { inhibitors }\end{array}$ & Treg & $\downarrow$ Tregs selectively & $\begin{array}{c}\uparrow \text { Significant } \\
\text { survival benefit }\end{array}$ & {$[58,59]$} \\
\hline PI3K inhibitors & TAM & $\downarrow$ TAM recruitment & Variable effects & [60] \\
\hline mTOR inhibitors & MDSC & Variable effects & Variable effects & {$[49,51]$} \\
\hline mTOR inhibitors & Endothelial cells & $\begin{array}{c}\downarrow \text { proliferation, } \\
\text { migration and } \\
\text { tubular structures } \\
\text { formation } \\
\uparrow \text { apoptosis }\end{array}$ & $\downarrow$ Angiogenesis & {$[33,61-63]$} \\
\hline mTORC1 inhibitor & CAF & $\begin{array}{l}\downarrow \text { CAF-secreted } \\
\text { cytokines }\end{array}$ & $\begin{array}{c}\downarrow \text { Of cell migration, } \\
\text { invasion, and } \\
\text { metastasis }\end{array}$ & {$[64]$} \\
\hline
\end{tabular}

\subsection{T Lymphocytes}

Emerging evidence highlights a central role for mTOR in bridging the immune signals and metabolic cues to direct lymphocyte proliferation, differentiation, and survival [65].

The lymphocyte activation increases protein, nucleotide, and lipid biosynthesis and utilizes aerobic glycolysis to generate ATP during the rapid proliferation $[40,66]$. The metabolic programs regulated by mTORC1 make it an important link between metabolism and immune function $[40,49]$.

\subsection{1. $\mathrm{CD}^{+}$}

$\mathrm{CD} 8^{+}$cytotoxic $\mathrm{T}$ cells, derived from naïve $\mathrm{CD} 8^{+} \mathrm{T}$ cells, are the major antitumor mechanism of the immune system because of their ability to target and kill cancer cells and maintain a memory response. Recently, mTOR has been identified as a regulator of memory $\mathrm{CD} 8^{+} \mathrm{T}$ cells differentiation [67]. It has been demonstrated that rapamycin modulates the $\mathrm{CD} 8^{+} \mathrm{T}$ cells induced by viral infection, showing that mTOR regulates the memory $\mathrm{CD}^{+} \mathrm{T}$ cells differentiation [68]. Indeed, it has been reported that mTORC1 negatively modulates the memory T cells formation [40].

Moreover, Pollizzi et al. [39] have demonstrated that mTORC1 and mTORC2 may play a different role in the regulation of $\mathrm{CD} 8^{+}$cells; mTORC1 positively influences the $\mathrm{CD} 8^{+} \mathrm{T}$ cells effector responses and glycolytic phenotype, while the mTORC2 activity is involved in the CD8 $8^{+} \mathrm{T}$ cells memory up-regulation. Moreover, the direct modulation of the mTOR-mediated lipid metabolism by the inactivation of the sterol regulatory element binding proteins (SREBP) pathway inhibits $\mathrm{CD}^{+} \mathrm{T}$-cell proliferation in vitro [69]. 


\subsection{2. $\mathrm{CD}^{+}$}

The activation of naïve $\mathrm{T}$ cells can result in the simultaneous expression of the tumor specific antigens, Th (T helper) 1, 17, and 2, and it is now clear that mTORC1 and mTORC2 promote T cells commitment [42]. Indeed, Delgoffe and collaborators demonstrated that the mTOR-deficient $\mathrm{CD}^{+} \mathrm{T}$ cells failed to differentiate into Th1, Th17, or Th2 effector cells in vitro or in vivo; the loss of Rheb, an upstream activator of mTORC1, inhibits the differentiation of both the Th1 and Th17 cells, whereas the Th2 cells differentiation requires mTORC1 activation but not Rheb [41,42]. The loss of Raptor induces Th17 cells differentiation [70]. According to the key role of mTOR in Th differentiation, Templeton and collaborators have demonstrated that treatment with everolimus induces a statistically significant reduction in the numbers of $\mathrm{CD}^{+}$and an increase in the Treg population, in a dose dependent manner in metastatic prostate cancer patients, with an increase in progression free survival [58].

Recent studies have shown that antigen stimulation causes $\mathrm{T}$ cells to transit from catabolism to anabolism, and mTOR regulates this process by enhancing the T cells metabolic activity [71]. In antigen-stimulated T cells, the mTOR activates the glycolytic program inducing the expression of MYC and HIF-1 $\alpha$, which in turn mediates the expression of glycolytic enzymes and transporters [72,73].

\subsubsection{Treg}

The forkhead box $3^{+}\left(\mathrm{FOXO}^{+}\right)$Tregs suppress inflammation and have an important role in tumor immunity through their role as a suppressor of the effector T cells. High numbers of Treg and a reduction of the $\mathrm{CD} 8^{+}$numbers in the tumor infiltrate are associated with a poor prognosis [40]. The reduction of mTOR signaling induces Treg expansion through the FOXO3 expression; in fact, as opposed to the $\mathrm{CD}^{+} \mathrm{T}$ cells, the mTOR axis regulates the lineage commitment between effector and regulatory $\mathrm{T}$ cells through the STAT transcription factor activation [41,74]. Despite the well-known role of the PI3K-AKTpathway in T-cell proliferation, the AKT and PI3K blockade selectively inhibits the Tregs' proliferation with minimal effect on the other T cells' population $\left(C D 4^{+}\right.$and $\left.C D 8^{+}\right)$. Indeed, the in vitro and in vivo studies display that the Tregs have an increased dependence on the PI3K-AKT signaling pathway, as compared to the other $\mathrm{T}$ cells [59].

Interestingly, mTOR may mediate different Treg functions, as demonstrated by the pharmacological and genetic modulation of the mTOR network. Indeed, the reduction of mTORC1 activity, by the deletion of Raptor, reduces the Treg function, and conversely, the over-activation of mTORC1 reduces the FOXO3 expression and converts Treg into effettor-like T cells, in TSC1-deficient models [44]. Moreover, the activation of mTORC2 in the PTEN-loss Tregs induces a reduction in their stability and their ability to differentiate $[45,46]$. It has been also demonstrated that the programming of the Treg suppressive functions is dependent on mTORC1; indeed, Zeng et al. have demonstrated that mTORC1 acts as a link between the immunological signals via the T cell receptor (TCR) and IL-2 to lipogenic pathways [75].

Recently, it has been reported that mTOR also modulates the role of PD-L1 as a regulator of the development, maintenance, and function of the induced regulatory T cells [76]. PD-1 is highly expressed on Treg cells and PD-L1 is widely expressed in several stroma non-hematopoietic cells and in various tumors; Lastwika and collaborators have shown that the activation of the mTOR pathway regulates the PD-L1 expression in vitro and in vivo in lung carcinoma $[77,78]$.

\subsection{TAMs}

TAMs are a class of immune cells that are present in high numbers in the TME and are recruited by soluble factors (cytokines and/or chemokines) or derived from tissue-resident macrophages. TAMs are generally classified into M1 and M2, depending on their polarization; M1 TAMs are involved in phagocyte-dependent inflammation and in antitumor response, whereas M2 TAMs inhibit the phagocytic function thereby being more tolerant towards tumor growth. However, it has been 
demonstrated that this is a simplification of the TAM's classification; Qian et al. showed that TAMs can share both M1 and M2 phenotype and functions, thus resulting in a difficult interpretation of their role in TME $[40,79,80]$.

Early evidence highlights the role of mTOR signaling in macrophage activation and differentiation. Indeed, Byles et al. showed that the loss of TSC1 activity in the macrophage leads to constitutive mTORC1 activation, and the consequent decrease in IL-4 production induces M2 polarization [47]. Consistent with these results, different studies demonstrated that the mTORC1 downregulation by different pharmacological and genetic approaches results in both decreased proinflammatory cytokine production by macrophages, with a consequent reduction of inflammation, and unbalances in macrophages M1 polarization [48,81]. Moreover, the role of the mTOR pathway in macrophage activity is involved not only in M1/M2 polarization, but also in processes, such as autophagy, which could indirectly influence the outcome of tumor progression. Indeed, Shan and collaborators demonstrated that rapamycin both reduces the M2 macrophage polarization by down-regulating PSTAT3 on the Tyr705 expression, and increases the autophagy [82].

Polarized macrophages also differ in terms of the cyto-/chemo-kines production, and M2 macrophages also exert their pro-tumoral activities by releasing specific cyto-/chemo-kines, which are involved in the key mechanisms in the tumor progression, such as angiogenesis [80]. Indeed, the M2 macrophages release IL-10, which in turn promotes VEGF production, and it has been demonstrated that rapamycin reduces angiogenesis by down-regulating the IL-10 and VEGF secretion [83].

mTORC2 also plays a critical role in M2 macrophages polarization; indeed, the inhibition of mTORC2 signaling in macrophages, by the deletion of rictor, reduces the differentiations of the M2 macrophages [84]. More recently, Shrivastava and colleagues demonstrated that mTORC2 up-regulates the M2 surface markers, CD206 and CD163, through the AKT axis, thus leading to an increase of the invasion and metastasis in mammary tumor models, both in in vitro and in mice [85].

\subsection{MDSCS}

MDSCs are a heterogeneous group of immature myeloid cells at various stages of differentiation, including precursors of macrophages, granulocytes, and dendritic cells (DC). Even if understanding the phenotypic and functional characteristics of the MDSCs is controversial, MDSCs can be classified in granulocyte or monocyte, based on the expression of Ly6C and Ly6G molecules, and play critical roles in primary and metastatic cancer progression. mTOR signaling is involved in the modulation of the MDSCs recruitment in TME, both in cancer cells and MDSCs; indeed, in cancer cells, the mTOR axis regulates the release of the soluble factors involved in the MDSCs recruitment, whereas in MDSCs, mTOR signaling affects the expression of specific antigen on their surface.

Welte et al. demonstrated that mTOR signaling promotes MDSCs accumulation by up-regulating granulocyte colony-stimulating factor (G-CSF) in breast cancer cells. Indeed, both the rapamycin treatment and the deletion of Raptor reduce the G-CSF levels [86]. Another soluble factor involved in the recruitment of MDSCs in TME is TGF- $\beta$, a cytokine that directly promotes the expression of $\mathrm{CD} 39^{+} / \mathrm{CD} 3^{+}$on the surface of myeloid cells, thereby exerting tumor-promoting roles [87]. Several studies in mouse models have demonstrated that the expression of these two ectonucleotidases leads to tumor cells' evasion from cytotoxic T cells responses, and that mTOR plays a critical role in the regulation of the CD39/CD73 expression. Indeed, it has been reported that rapamycin abrogates the TGF- $\beta$-mediated induction of CD39/CD73 expression, by HIF- $1 \alpha$ [50].

Despite the role of mTOR, described above, in enhancing pro-tumoral MDSCs accumulation, other groups demonstrate an opposite aspect of the MDSCs recruitment mTOR-mediated, highlighting the controversial function of the MDSCs in TME. Indeed, it has been demonstrated that the rapamycin treatment upregulates the recruitment and the induction of MDSCs' immunosuppressive ability, by enhancing the production of IL-1 and IL-2, and by upregulating the expression of their effectors, arginase-1 and inducible nitric oxide synthase, which prevents T-cell proliferation [51]. 
Moreover, MDSCs can also affect tumor progression by modulating the commitment of the $\mathrm{TME}^{\prime}$ components. Indeed, preliminary in vitro studies indicate a potential role of MDSCs in mTOR-mediated $\mathrm{CD} 8^{+} \mathrm{T}$ cells differentiation into effector populations [88].

\section{5. mTOR and Angiogenesis}

TME is composed not only of the cells of the immune system, but also of tumor vasculature, and angiogenesis has long been recognized as a hallmark of cancer [89]. Angiogenesis represents the mechanism by which new blood vessels develop, and it is a dynamic and tightly regulated process, mainly induced by hypoxia [27]. During the tumor progression, pathological angiogenesis is driven by the presence of pro-angiogenic factors in TME, such as VEGF-A and IL-8. Several cells, including tumor and tumor-associated stromal cells (such as endothelial cell and macrophages), are involved in this process, in part, by secreting growth factors and cytokines [27].

The VEGF/VEGF receptor (VEGFR) axis is one of the key regulators of angiogenesis, as demonstrated by the use of anti-VEGF/VEGFR drugs, to inhibit angiogenesis in cancer therapy, and it is regulated, among others, by the PI3K-AKT-mTOR signaling pathway $[33,90]$. Indeed, mTORC1 regulates the HIF-1/HIF-2, which are the transcription factors for the hypoxic stress response genes, including VEGF and TGF- $\alpha[6,91]$. HIF-1, the predominant form, is a heterodimer consisting of HIF- $1 \alpha$ and HIF- $1 \beta$ subunits; although HIF- $1 \beta$ is constitutively expressed, the stability of HIF- $1 \alpha$ is dependent on oxygen levels [92]. In the presence of $\mathrm{O}_{2}$, the ubiquitination of HIF- $1 \alpha$ induces its degradation by the $26 \mathrm{~S}$ proteasome, whereas under hypoxic conditions, the accumulation of the HIF- $1 \alpha$ subunit is because of a decrease in the rate of proteolytic degradation [92].

In addition to the HIF protein stability regulation, other mechanisms of the HIF- $1 \alpha$ expression have been proposed at different levels, such as mRNA transcription and translation [93]. Recently, Dodd and colleagues demonstrated that mTORC1 enhances the transcription of HIF- $1 \alpha$ mRNA, by directly phosphorylating STAT3 at Ser727 [94]. The same group also showed that mTORC1 regulates the HIF-1 $\alpha$ translation, through the activity of both $\mathrm{p} 70^{S 6 \mathrm{~K} 1}$ and elongation initiation factor (EIF)-4E binding protein 1 (4E-BP1) [94]. Conversely, several studies reported that long-lasting hypoxic conditions downregulate $\mathrm{mTORC} 1$ activity, by activating the negative $\mathrm{mTORC} 1$ regulators tuberous sclerosis complex TSC1-2 or 5'-AMP activated protein Kinase $\beta$ (AMPK- $\beta$ ), which in turn phosphorylates Raptor on Ser722/792 [95,96].

This tight connection between the mTOR pathway and angiogenesis regulation is also maintained in endothelial cells, as demonstrated by the effects of the mTOR inhibitors. Indeed, several groups showed that rapamycin displays anti-angiogenic properties in terms of a reduction of the proliferation, migration, tubular structures formation and an increase of apoptosis [61-63]. Our previous data also demonstrated that the mTOR inhibitor temsirolimus inhibits serum- and/or VEGF-driven endothelial cell proliferation and vessel formation in vitro and in vivo [33]. Specific knock-down experiments of mTORC1/2 interactors in endothelial cells confirmed the role of mTOR in angiogenesis; indeed, knocking-down TSC1, a negative regulator of $\mathrm{MTORC1}$, increases the proliferation of endothelial cells, whereas the deletion of rictor, a positive regulator of mTORC1, reduces cell proliferation [52,53].

As reviewed by De Palma and others, hematopoietic-derived tumor-infiltrating cells also regulate angiogenesis, by releasing growth factors and inflammatory cytokines in the TME [27]. Among them, TAMs play a critical role in tumor angiogenesis, because they exert a dual role, in both the inhibition and activation of angiogenesis [97]. Interestingly, even in TAMs, the mTOR activity displays a key role in promoting angiogenesis and polarization into the M1 phenotype [81]. Moreover, macrophages secrete pro-angiogenic factors such as VEGF-A, IL-1 $\beta$, IL-8, and metalloproteases (MMP) 2 and 9, which are released also by other tumor infiltrating cells, such as neutrophils, eosinophils, natural killers, and CAFs [27]. $\mathrm{O}_{2}$ deprivation in specific tumor areas is a critical cue for the accumulation of TAMs, which are recruited by a hypoxia-induced chemoattractant gradient, such as VEGF, and endothelins [24]. 
Even if mTOR is a key regulator of HIF-1, the activation of other signaling pathways, which converge on the targets shared with the PI3K network, can also promote tumor angiogenesis. For example, the epidermal growth factor receptor (EGFR) activation increases the transcription of VEGF via the PI3K pathway, but not dependently on HIF-1, in glioblastoma cells; moreover, the EGFR amplification has an additive effect with a PTEN loss of function in increasing the VEGF levels, by enhancing the VEGF promoter activity $[98,99]$. Zundel and colleagues have demonstrated that in glioblastoma cell lines, a loss of PTEN results in HIF-1 stabilization which in turn causes the up-regulation of VEGF expression [100]. The loss of PTEN is a common mechanism of PI3K activation in several cancers, and its association with higher levels of secreted VEGF was observed also in other cancer cell lines with a different histological origin, such as pancreatic and prostate cancer cells, suggesting that PTEN plays a critical role in angiogenesis and tumorigenesis $[101,102]$.

\section{6. mTOR in CAFs Regulation}

CAFs are cellular components of the stroma derived from the activated quiescent fibroblasts surrounding cancer cells, that directly promote tumor initiation, progression and metastasis by secreting growth factors, cytokines, and a large number of metabolites [103-105]. Moreover, the CAFs regulate normal epithelial differentiation and homeostasis, and cancer progression, particularly in stroma-rich tumors, like pancreatic cancers [106]. Indeed, in pancreatic ductal adenocarcinoma (PDAC), the stroma forms more than $80 \%$ of the tumor mass, and the CAFs express $\alpha$-SMA (alpha-smooth muscle actin) and are also called activated pancreatic stellate cells [106]. Several studies demonstrated that CAFs display pro-tumorigenic properties by promoting invasion and metastasis in a non-vascular manner [107,108].

Similarly, recent evidence has showed that pancreatic CAFs may be involved in resistance to anticancer drugs [109,110]. Indeed, Duluc et al. demonstrated that, in pancreatic CAFs, the PI3K/mTOR pathway is activated by the autocrine secretion of PDGF and Janus kinase (JAK)2-dependent cytokines [54]. The CAFs also express the sst1 somatostatin receptor, whose activation inhibits the mTOR/4E-BP1 pathway, which in turn modulates the synthesis of the secreted proteins involved in the resistance to cancer drug therapies, including IL-6 and STAT3, and could be a possible upstream regulator of the IL- 6 expression. These results suggest that counteracting the mTOR/IL-6 driven resistance might increase the effectiveness of the anticancer therapy [54,111]. Moreover, the specific inhibition of $\mathrm{mTORC} 1$ can also reverse the CAF-induced resistance through JAK/STAT3-, ERK- and AKT-signaling. Everolimus treatment, indeed, induces a significant reduction of the secretion of cytokines, such as IL-8, IL-13, and MCP-1, which are involved in the promotion of tumor cells' proliferation and migration [64].

Wang et al. demonstrated that CAFs promoted irradiated cancer cell recovery through the increase of autophagy, thus causing a tumor relapse after radiation therapy. Indeed, they ensured that CAFs, through the production of IGF1/2, IL-12, and $\beta$-hydroxybutyrate, were capable of inducing autophagy in cancer cells post-radiation, thus increasing the level of reactive oxygen species (ROS), which in turn enhances protein phosphatase 2 (PP2)A activity, blocks mTORC1 activation, and induces autophagy in cancer cells [112].

\section{Implications in Cancer Immunotherapy}

In addition to the central role of the PI3K/AKT/mTOR signaling network dysregulation in cancer cells, recent evidence highlights that targeting this pathway can also impact on the host immunity [17]. In the past years, the host's immune system has become a target for the development of new therapeutic strategies, such as immunomodulatory drugs or monoclonal antibodies, and cancer immunotherapy has achieved remarkable clinical efficacy in the treatment of many cancer patients, by promoting the antitumor activity of the immune system [4]. More specifically, two immune checkpoints have achieved the most attention so far, as follows: the cell surface protein PD-1 is expressed by activated T cells and the binding with its two ligands, PD-L1 and PD-L2, attenuates the activity of the T cells and the effector 
responses; CTLA-4 is a negative regulator of T cells, by competing with the co-stimulatory molecule CD28 for the binding to the ligands CD80 and CD86 [113]. The recruitment of regulatory immune cells can also mediate immune suppression; indeed, the modulation of $\mathrm{T}$ cell-mediated antitumor responses represents another therapeutic strategy [114]. Although blocking these checkpoints and the T cell-mediated immunotherapy exhibit clinical success, the majority of patients still fail to respond to immunotherapy, thus understanding the molecular mechanisms of resistance remains crucial to select a specific subset of patients and improve the overall survival [115].

As highlighted above, mTOR plays a central role in coordinating the environmental stimuli and cell metabolic responses, also because of its function in immune cell homeostasis and activation, and thus represents a potential target for cancer immunotherapy [116]. The first evidence of the tight connection between mTOR and immune regulatory targets was demonstrated by the immunosuppressive properties of the mTOR inhibitor rapamycin, because of its ability to block T cells proliferation [117]. In the last years, PD-L1 regulation has become the focus of many studies and several groups demonstrated that the PI3K/AKT/mTOR pathway regulates PD-L1 in different tumors, such as in non-small cell lung cancer [78]. As PI3K activation may occur via the loss of PTEN, it has been further reported that the loss of this tumor suppressor may induce the overexpression of PD-L1 and immunoresistance in several tumors of different histological origin (i.e., glioma, leiomyosarcoma, colorectal, breast cancer, and PDAC [118-122]. Mittendorf and her group also demonstrated that treatments with either the AKT inhibitor, MK-2206, or the mTOR inhibitor, rapamycin, significantly decreases the PD-L1 mRNA transcripts in the PTEN-mutant triple-negative breast cancer cell lines [121]. More recently, it has been also demonstrated that a loss of the PTEN expression correlates with a decrease of $\mathrm{CD}^{+} \mathrm{T}$ cells' infiltration in melanoma and poor outcomes to immunotherapies, regardless of BRAF and NRAS status [56]. As opposed to PTEN, mTORC1 displays a controversial role in $\mathrm{CD} 8^{+} \mathrm{T}$ cells; indeed, the mTORC1 activity is required for their effector functions, and the inhibiting mTORC1 activity displays paradoxical immune stimulating effects by promoting memory $\mathrm{CD} 8^{+}$generation in a dose- and duration-dependent manner, as well [40].

$\mathrm{CD}^{+} \mathrm{T}$ cells are not the only regulators of the adaptive immune response involved in cancer immunotherapy; the dysregulation of $\mathrm{CD}^{+}$Treg cells are also involved in several pathological immune diseases and drug resistance. The mTOR and dual PI3K/mTOR inhibitors have been shown to induce Tregs' expansion and their immunosuppressive activity, thus correlating with a poor prognosis in cancer patients [123]. Encouragingly, Huijts and her group showed that the PI3K inhibition alone allows for the expansion of Tregs, but without affecting their overall suppressive activity [124].

In addition to the upregulation of Treg into tumor tissues, mTOR signaling stimulates also the infiltration of MDSCs, thus allowing for it to combine immunotherapy with PI3K-AKT-mTOR pathway inhibitors. The activation of toll-like receptors (TLR) on DCs leads to their maturation, and the TLR signaling activates PI3K; this evidence highlights the synergistic effects of the combined PI3K inhibitors with TLR agonists in mouse models [125].

\section{Conclusions}

The PI3K/AKT/mTOR network plays a significant role in the regulation of several processes in tumor initiation and progression, by controlling the protein synthesis, proliferation, growth, and survival in cancer cells on the one hand, and by affecting the characterization and the activity of the TME's elements on the other hand. The involvement of TME in cancer progression and drug resistance is well recognized, thus leading to a necessity to better investigate the molecular mechanisms of tumor-stroma interactions (TSI). Thus, targeting the molecular mediators of TSIs, such the elements of the mTOR network, may provide an excellent strategy for therapeutic opportunities.

Funding: This research was funded by the Italian Association for Cancer Research (AIRC) (Michele Milella, IG18622; Emilio Bria IG20583), the Fondazione Cariverona (Emilio Bria and Sara Pilotto, 2015.0872), and the International Association for the Study of Lung Cancer (IASLC, Emilio Bria and Sara Pilotto). 
Acknowledgments: Chiara Bazzichetto is a PhD student at the Doctoral School in Immunological, Hematological, and Rheumatologic Sciences.

Conflicts of Interest: The authors declare no conflict of interest.

\section{Abbreviations}

\begin{tabular}{|c|c|}
\hline AMPK- $\beta$ & $5^{\prime}$-AMP activated protein kinase $\beta$ \\
\hline CAF & cancer-associated fibroblasts \\
\hline CTLA-4 & cytotoxic t-lymphocyte protein 4 \\
\hline DC & dendridic cell \\
\hline DEPTOR & DEP domain-containing mTOR interacting protein \\
\hline ECM & extracellular matrix \\
\hline EGFR & epidermal growth factor receptor \\
\hline FOXO & forkhead box \\
\hline G-CSF & granulocyte colony-stimulating factor \\
\hline HIF & hypoxia-inducible factor \\
\hline Hsp70 & heat shock protein 70 \\
\hline IGF & insulin growth factor \\
\hline IL & interleukin \\
\hline JAK & Janus kinase \\
\hline MDSC & myeloid-derived suppressor cells \\
\hline mLST8 & mammalian lethal with sec 13 protein 8 \\
\hline MMP & metalloproteases \\
\hline mSIN1 & mammalian stress-activated protein kinase interacting protein 1 \\
\hline mTOR & mammalian target of rapamycin \\
\hline mTORC & mTOR complex \\
\hline PD-1 & programmed death 1 \\
\hline PDAC & pancreatic ductal adenocarcinoma \\
\hline PDGF & plated-derived growth factor \\
\hline PDK1 & phosphoinositide-dependent kinase- 1 \\
\hline PIP2 & phosphatidylinositol 4,5-bisphosphate \\
\hline PIP3 & phosphatidylinositol 3,4,5-trisphosphate \\
\hline PI3K & phosphoinositide 3-kinase \\
\hline PKC & protein kinase $\mathrm{C}$ \\
\hline PP2 & protein phosphatase 2 \\
\hline PRAS40 & proline-rich AKT substrate 40 \\
\hline PRR & proline-rich protein \\
\hline Protor & protein observed with rictor \\
\hline PTEN & phosphatase and tensin homolog on chromosome 10 \\
\hline $\mathrm{p} 70^{\mathrm{S} 6 \mathrm{~K} 1}$ & p70 ribosomal protein $S 6$ kinase 1 \\
\hline ROS & reactive oxygen species \\
\hline SGK & serum and glucocorticoid kinase \\
\hline SREBP & sterol regulatory element binding proteins \\
\hline STAT & signal transducer and activator of transcription \\
\hline TAM & tumor-associated macrophages \\
\hline TCR & $\mathrm{T}$ cell receptor \\
\hline Tel2 & telomere maintenance 2 \\
\hline TGF & trasforming growth factor \\
\hline Th & T helper \\
\hline TLR & tool-like receptor \\
\hline TME & tumor microenvironment \\
\hline Treg & regulatory $\mathrm{T}$ cells \\
\hline TSC & tuberous sclerosis complexes \\
\hline TSI & tumor-stroma interactions \\
\hline
\end{tabular}


Tti1 tel2-interacting protein 1

VEGF vascular endothelial growth factor

VEGFR VEGF receptor

4EBP-1 4E binding protein-1

\section{References}

1. Conciatori, F.; Ciuffreda, L.; Bazzichetto, C.; Falcone, I.; Pilotto, S.; Bria, E.; Cognetti, F.; Milella, M. mTOR Cross-Talk in Cancer and Potential for Combination Therapy. Cancers (Basel) 2018, 10, 23. [CrossRef] [PubMed]

2. Saxton, R.A.; Sabatini, D.M. mTOR Signaling in Growth, Metabolism, and Disease. Cell 2017, 169, 361-371. [CrossRef] [PubMed]

3. Kim, L.C.; Cook, R.S.; Chen, J. mTORC1 and mTORC2 in cancer and the tumor microenvironment. Oncogene 2017, 36, 2191-2201. [CrossRef] [PubMed]

4. Schaaf, M.B.; Garg, A.D.; Agostinis, P. Defining the role of the tumor vasculature in antitumor immunity and immunotherapy. Cell Death Dis. 2018, 9, 115. [CrossRef] [PubMed]

5. Karar, J.; Maity, A. PI3K/AKT/mTOR Pathway in Angiogenesis. Front. Mol. Neurosci. 2011, 4, 51. [CrossRef] [PubMed]

6. Laughner, E.; Taghavi, P.; Chiles, K.; Mahon, P.C.; Semenza, G.L. HER2 (neu) signaling increases the rate of hypoxia-inducible factor 1alpha (HIF-1alpha) synthesis: Novel mechanism for HIF-1-mediated vascular endothelial growth factor expression. Mol. Cell Biol. 2001, 21, 3995-4004. [CrossRef] [PubMed]

7. Brown, E.J.; Albers, M.W.; Shin, T.B.; Ichikawa, K.; Keith, C.T.; Lane, W.S.; Schreiber, S.L. A mammalian protein targeted by G1-arresting rapamycin-receptor complex. Nature 1994, 369, 756-758. [CrossRef] [PubMed]

8. Chiu, M.I.; Katz, H.; Berlin, V. RAPT1, a mammalian homolog of yeast Tor, interacts with the FKBP12/rapamycin complex. Proc. Natl. Acad. Sci. USA 1994, 91, 12574-12578. [CrossRef] [PubMed]

9. Jacinto, E.; Loewith, R.; Schmidt, A.; Lin, S.; Ruegg, M.A.; Hall, A.; Hall, M.N. Mammalian TOR complex 2 controls the actin cytoskeleton and is rapamycin insensitive. Nat. Cell Biol. 2004, 6, 1122-1128. [CrossRef] [PubMed]

10. Sarbassov, D.D.; Ali, S.M.; Kim, D.H.; Guertin, D.A.; Latek, R.R.; Erdjument-Bromage, H.; Tempst, P.; Sabatini, D.M. Rictor, a novel binding partner of mTOR, defines a rapamycin-insensitive and raptor-independent pathway that regulates the cytoskeleton. Curr. Biol. 2004, 14, 1296-1302. [CrossRef] [PubMed]

11. Thomanetz, V.; Angliker, N.; Cloetta, D.; Lustenberger, R.M.; Schweighauser, M.; Oliveri, F.; Suzuki, N.; Ruegg, M.A. Ablation of the mTORC2 component rictor in brain or Purkinje cells affects size and neuron morphology. J. Cell Biol. 2013, 201, 293-308. [CrossRef] [PubMed]

12. Zhang, H.; Bajraszewski, N.; Wu, E.; Wang, H.; Moseman, A.P.; Dabora, S.L.; Griffin, J.D.; Kwiatkowski, D.J. PDGFRs are critical for PI3K/Akt activation and negatively regulated by mTOR. J. Clin. Investig. 2007, 117, 730-738. [CrossRef] [PubMed]

13. Willems, L.; Tamburini, J.; Chapuis, N.; Lacombe, C.; Mayeux, P.; Bouscary, D. PI3K and mTOR signaling pathways in cancer: New data on targeted therapies. Curr. Oncol. Rep. 2012, 14, 129-138. [CrossRef] [PubMed]

14. Sarbassov, D.D.; Guertin, D.A.; Ali, S.M.; Sabatini, D.M. Phosphorylation and regulation of Akt/PKB by the rictor-mTOR complex. Science 2005, 307, 1098-1101. [CrossRef] [PubMed]

15. Milella, M.; Falcone, I.; Conciatori, F.; Cesta Incani, U.; Del Curatolo, A.; Inzerilli, N.; Nuzzo, C.M.; Vaccaro, V.; Vari, S.; Cognetti, F.; et al. PTEN: Multiple Functions in Human Malignant Tumors. Front. Oncol. 2015, 5, 24. [CrossRef] [PubMed]

16. Ciuffreda, L.; McCubrey, J.A.; Milella, M. Signaling intermediates (PI3K/PTEN/AKT/mTOR and $\mathrm{RAF} / \mathrm{MEK} / \mathrm{ERK}$ pathways) as therapeutic targets for anti-cancer and anti-angiogenesis treatments. Curr. Signal. Transd. Ther. 2009, 4, 130-143. [CrossRef]

17. Xue, G.; Zippelius, A.; Wicki, A.; Mandala, M.; Tang, F.; Massi, D.; Hemmings, B.A. Integrated Akt/PKB signaling in immunomodulation and its potential role in cancer immunotherapy. J. Natl. Cancer Inst. 2015, 107, 7. [CrossRef] [PubMed] 
18. Wang, M.; Zhao, J.; Zhang, L.; Wei, F.; Lian, Y.; Wu, Y.; Gong, Z.; Zhang, S.; Zhou, J.; Cao, K.; et al. Role of tumor microenvironment in tumorigenesis. J. Cancer 2017, 8, 761-773. [CrossRef] [PubMed]

19. Kenny, P.A.; Lee, G.Y.; Bissell, M.J. Targeting the tumor microenvironment. Front. Biosci. 2007, 12, 3468-3474. [CrossRef] [PubMed]

20. Balkwill, F.R.; Capasso, M.; Hagemann, T. The tumor microenvironment at a glance. J. Cell Sci. 2012, 125, 5591-5596. [CrossRef] [PubMed]

21. Hanahan, D.; Coussens, L.M. Accessories to the crime: Functions of cells recruited to the tumor microenvironment. Cancer Cell 2012, 21, 309-322. [CrossRef] [PubMed]

22. Chen, F.; Zhuang, X.; Lin, L.; Yu, P.; Wang, Y.; Shi, Y.; Hu, G.; Sun, Y. New horizons in tumor microenvironment biology: Challenges and opportunities. BMC Med. 2015, 13, 45. [CrossRef] [PubMed]

23. Zumsteg, A.; Christofori, G. Corrupt policemen: Inflammatory cells promote tumor angiogenesis. Curr. Opin. Oncol. 2009, 21, 60-70. [CrossRef] [PubMed]

24. Murdoch, C.; Giannoudis, A.; Lewis, C.E. Mechanisms regulating the recruitment of macrophages into hypoxic areas of tumors and other ischemic tissues. Blood 2004, 104, 2224-2234. [CrossRef] [PubMed]

25. Lawrence, T.; Natoli, G. Transcriptional regulation of macrophage polarization: Enabling diversity with identity. Nat. Rev. Immunol. 2011, 11, 750-761. [CrossRef] [PubMed]

26. Chaudhary, B.; Elkord, E. Regulatory T Cells in the Tumor Microenvironment and Cancer Progression: Role and Therapeutic Targeting. Vaccines (Basel) 2016, 4, 28. [CrossRef] [PubMed]

27. De Palma, M.; Biziato, D.; Petrova, T.V. Microenvironmental regulation of tumour angiogenesis. Nat. Rev. Cancer 2017, 17, 457-474. [CrossRef] [PubMed]

28. Gattazzo, F.; Urciuolo, A.; Bonaldo, P. Extracellular matrix: A dynamic microenvironment for stem cell niche. Biochim. Biophys. Acta 2014, 1840, 2506-2519. [CrossRef] [PubMed]

29. Popovic, Z.V.; Sandhoff, R.; Sijmonsma, T.P.; Kaden, S.; Jennemann, R.; Kiss, E.; Tone, E.; Autschbach, F.; Platt, N.; Malle, E.; et al. Sulfated glycosphingolipid as mediator of phagocytosis: SM4s enhances apoptotic cell clearance and modulates macrophage activity. J. Immunol. 2007, 179, 6770-6782. [CrossRef] [PubMed]

30. Nagarsheth, N.; Wicha, M.S.; Zou, W. Chemokines in the cancer microenvironment and their relevance in cancer immunotherapy. Nat. Rev. Immunol. 2017, 17, 559-572. [CrossRef] [PubMed]

31. Landskron, G.; De la Fuente, M.; Thuwajit, P.; Thuwajit, C.; Hermoso, M.A. Chronic inflammation and cytokines in the tumor microenvironment. J. Immunol. Res. 2014, 2014, 149185. [CrossRef] [PubMed]

32. Zlotnik, A.; Yoshie, O. Chemokines: A new classification system and their role in immunity. Immunity 2000, 12, 121-127. [CrossRef]

33. Del Bufalo, D.; Ciuffreda, L.; Trisciuoglio, D.; Desideri, M.; Cognetti, F.; Zupi, G.; Milella, M. Antiangiogenic potential of the Mammalian target of rapamycin inhibitor temsirolimus. Cancer Res. 2006, 66, 5549-5554. [CrossRef] [PubMed]

34. Milella, M.; Falcone, I.; Conciatori, F.; Matteoni, S.; Sacconi, A.; De Luca, T.; Bazzichetto, C.; Corbo, V.; Simbolo, M.; Sperduti, I.; et al. PTEN status is a crucial determinant of the functional outcome of combined MEK and mTOR inhibition in cancer. Sci. Rep. 2017, 7, 43013. [CrossRef] [PubMed]

35. De la Iglesia, N.; Konopka, G.; Lim, K.L.; Nutt, C.L.; Bromberg, J.F.; Frank, D.A.; Mischel, P.S.; Louis, D.N.; Bonni, A. Deregulation of a STAT3-interleukin 8 signaling pathway promotes human glioblastoma cell proliferation and invasiveness. J. Neurosci. 2008, 28, 5870-5878. [CrossRef] [PubMed]

36. Maxwell, P.J.; Coulter, J.; Walker, S.M.; McKechnie, M.; Neisen, J.; McCabe, N.; Kennedy, R.D.; Salto-Tellez, M.; Albanese, C.; Waugh, D.J. Potentiation of inflammatory CXCL8 signalling sustains cell survival in PTEN-deficient prostate carcinoma. Eur. Urol. 2013, 64, 177-188. [CrossRef] [PubMed]

37. Weichhart, T.; Hengstschlager, M.; Linke, M. Regulation of innate immune cell function by mTOR. Nat. Rev. Immunol. 2015, 15, 599-614. [CrossRef] [PubMed]

38. Thomson, A.W.; Turnquist, H.R.; Raimondi, G. Immunoregulatory functions of mTOR inhibition. Nat. Rev. Immunol. 2009, 9, 324-337. [CrossRef] [PubMed]

39. Pollizzi, K.N.; Patel, C.H.; Sun, I.H.; Oh, M.H.; Waickman, A.T.; Wen, J.; Delgoffe, G.M.; Powell, J.D. mTORC1 and mTORC2 selectively regulate CD8(+) T cell differentiation. J. Clin. Investig. 2015, 125, 2090-2108. [CrossRef] [PubMed]

40. Zeng, H. mTOR signaling in immune cells and its implications for cancer immunotherapy. Cancer Lett. 2017, 408, 182-189. [CrossRef] [PubMed] 
41. Delgoffe, G.M.; Kole, T.P.; Zheng, Y.; Zarek, P.E.; Matthews, K.L.; Xiao, B.; Worley, P.F.; Kozma, S.C.; Powell, J.D. The mTOR kinase differentially regulates effector and regulatory $\mathrm{T}$ cell lineage commitment. Immunity 2009, 30, 832-844. [CrossRef] [PubMed]

42. Delgoffe, G.M.; Pollizzi, K.N.; Waickman, A.T.; Heikamp, E.; Meyers, D.J.; Horton, M.R.; Xiao, B.; Worley, P.F.; Powell, J.D. The kinase mTOR regulates the differentiation of helper $\mathrm{T}$ cells through the selective activation of signaling by mTORC1 and mTORC2. Nat. Immunol. 2011, 12, 295-303. [CrossRef] [PubMed]

43. Lee, K.; Gudapati, P.; Dragovic, S.; Spencer, C.; Joyce, S.; Killeen, N.; Magnuson, M.A.; Boothby, M. Mammalian target of rapamycin protein complex 2 regulates differentiation of Th1 and Th2 cell subsets via distinct signaling pathways. Immunity 2010, 32, 743-753. [CrossRef] [PubMed]

44. Park, Y.; Jin, H.S.; Lopez, J.; Elly, C.; Kim, G.; Murai, M.; Kronenberg, M.; Liu, Y.C. TSC1 regulates the balance between effector and regulatory T cells. J. Clin. Investig. 2013, 123, 5165-5178. [CrossRef] [PubMed]

45. Huynh, A.; DuPage, M.; Priyadharshini, B.; Sage, P.T.; Quiros, J.; Borges, C.M.; Townamchai, N.; Gerriets, V.A.; Rathmell, J.C.; Sharpe, A.H.; et al. Control of PI(3) kinase in Treg cells maintains homeostasis and lineage stability. Nat. Immunol. 2015, 16, 188-196. [CrossRef] [PubMed]

46. Shrestha, S.; Yang, K.; Guy, C.; Vogel, P.; Neale, G.; Chi, H. Treg cells require the phosphatase PTEN to restrain TH1 and TFH cell responses. Nat. Immunol. 2015, 16, 178-187. [CrossRef] [PubMed]

47. Byles, V.; Covarrubias, A.J.; Ben-Sahra, I.; Lamming, D.W.; Sabatini, D.M.; Manning, B.D.; Horng, T. The TSC-mTOR pathway regulates macrophage polarization. Nat. Commun. 2013, 4, 2834. [CrossRef] [PubMed]

48. Jiang, H.; Westerterp, M.; Wang, C.; Zhu, Y.; Ai, D. Macrophage mTORC1 disruption reduces inflammation and insulin resistance in obese mice. Diabetologia 2014, 57, 2393-2404. [CrossRef] [PubMed]

49. Guri, Y.; Nordmann, T.M.; Roszik, J. mTOR at the Transmitting and Receiving Ends in Tumor Immunity. Front. Immunol. 2018, 9, 578. [CrossRef] [PubMed]

50. Li, J.; Wang, L.; Chen, X.; Li, L.; Li, Y.; Ping, Y.; Huang, L.; Yue, D.; Zhang, Z.; Wang, F.; et al. CD39/CD73 upregulation on myeloid-derived suppressor cells via TGF-beta-mTOR-HIF-1 signaling in patients with non-small cell lung cancer. Oncoimmunology 2017, 6, e1320011. [CrossRef] [PubMed]

51. Zhang, C.; Wang, S.; Li, J.; Zhang, W.; Zheng, L.; Yang, C.; Zhu, T.; Rong, R. The mTOR signal regulates myeloid-derived suppressor cells differentiation and immunosuppressive function in acute kidney injury. Cell Death Dis. 2017, 8, e2695. [CrossRef] [PubMed]

52. Sun, S.; Chen, S.; Liu, F.; Wu, H.; McHugh, J.; Bergin, I.L.; Gupta, A.; Adams, D.; Guan, J.L. Constitutive Activation of mTORC1 in Endothelial Cells Leads to the Development and Progression of Lymphangiosarcoma through VEGF Autocrine Signaling. Cancer Cell 2015, 28, 758-772. [CrossRef] [PubMed]

53. Wang, S.; Amato, K.R.; Song, W.; Youngblood, V.; Lee, K.; Boothby, M.; Brantley-Sieders, D.M.; Chen, J. Regulation of endothelial cell proliferation and vascular assembly through distinct mTORC2 signaling pathways. Mol. Cell. Biol. 2015, 35, 1299-1313. [CrossRef] [PubMed]

54. Duluc, C.; Moatassim-Billah, S.; Chalabi-Dchar, M.; Perraud, A.; Samain, R.; Breibach, F.; Gayral, M.; Cordelier, P.; Delisle, M.B.; Bousquet-Dubouch, M.P.; et al. Pharmacological targeting of the protein synthesis mTOR/4E-BP1 pathway in cancer-associated fibroblasts abrogates pancreatic tumour chemoresistance. EMBO Mol. Med. 2015, 7, 735-753. [CrossRef] [PubMed]

55. Ahmad, S.; Abu-Eid, R.; Shrimali, R.; Webb, M.; Verma, V.; Doroodchi, A.; Berrong, Z.; Samara, R.; Rodriguez, P.C.; Mkrtichyan, M.; et al. Differential PI3Kdelta Signaling in CD4(+) T-cell Subsets Enables Selective Targeting of T Regulatory Cells to Enhance Cancer Immunotherapy. Cancer Res. 2017, 77, 1892-1904. [CrossRef] [PubMed]

56. Peng, W.; Chen, J.Q.; Liu, C.; Malu, S.; Creasy, C.; Tetzlaff, M.T.; Xu, C.; McKenzie, J.A.; Zhang, C.; Liang, X.; et al. Loss of PTEN Promotes Resistance to T Cell-Mediated Immunotherapy. Cancer Discov. 2016, 6, 202-216. [CrossRef] [PubMed]

57. Dong, Y.; Richards, J.A.; Gupta, R.; Aung, P.P.; Emley, A.; Kluger, Y.; Dogra, S.K.; Mahalingam, M.; Wajapeyee, N. PTEN functions as a melanoma tumor suppressor by promoting host immune response. Oncogene 2014, 33, 4632-4642. [CrossRef] [PubMed]

58. Templeton, A.J.; Dutoit, V.; Cathomas, R.; Rothermundt, C.; Bartschi, D.; Droge, C.; Gautschi, O.; Borner, M.; Fechter, E.; Stenner, F.; et al. Swiss Group for Clinical Cancer, R., Phase 2 trial of single-agent everolimus in chemotherapy-naive patients with castration-resistant prostate cancer (SAKK 08/08). Eur. Urol. 2013, 64, 150-158. [CrossRef] [PubMed] 
59. Abu-Eid, R.; Samara, R.N.; Ozbun, L.; Abdalla, M.Y.; Berzofsky, J.A.; Friedman, K.M.; Mkrtichyan, M.; Khleif, S.N. Selective inhibition of regulatory T cells by targeting the PI3K-Akt pathway. Cancer Immunol. Res. 2014, 2, 1080-1089. [CrossRef] [PubMed]

60. Schmid, M.C.; Avraamides, C.J.; Dippold, H.C.; Franco, I.; Foubert, P.; Ellies, L.G.; Acevedo, L.M.; Manglicmot, J.R.; Song, X.; Wrasidlo, W.; et al. Receptor tyrosine kinases and TLR/IL1Rs unexpectedly activate myeloid cell PI3kgamma, a single convergent point promoting tumor inflammation and progression. Cancer Cell 2011, 19, 715-727. [CrossRef] [PubMed]

61. Vinals, F.; Chambard, J.C.; Pouyssegur, J. p70 S6 kinase-mediated protein synthesis is a critical step for vascular endothelial cell proliferation. J. Biol. Chem. 1999, 274, 26776-26782. [CrossRef] [PubMed]

62. Dormond, O.; Madsen, J.C.; Briscoe, D.M. The effects of mTOR-Akt interactions on anti-apoptotic signaling in vascular endothelial cells. J. Biol. Chem. 2007, 282, 23679-23686. [CrossRef] [PubMed]

63. Shinohara, E.T.; Cao, C.; Niermann, K.; Mu, Y.; Zeng, F.; Hallahan, D.E.; Lu, B. Enhanced radiation damage of tumor vasculature by mTOR inhibitors. Oncogene 2005, 24, 5414-5422. [CrossRef] [PubMed]

64. Heits, N.; Heinze, T.; Bernsmeier, A.; Kerber, J.; Hauser, C.; Becker, T.; Kalthoff, H.; Egberts, J.H.; Braun, F. Influence of mTOR-inhibitors and mycophenolic acid on human cholangiocellular carcinoma and cancer associated fibroblasts. BMC Cancer 2016, 16, 322. [CrossRef] [PubMed]

65. Zeng, H.; Chi, H. mTOR and lymphocyte metabolism. Curr. Opin. Immunol. 2013, 25, 347-355. [CrossRef] [PubMed]

66. Deberardinis, R.J.; Sayed, N.; Ditsworth, D.; Thompson, C.B. Brick by brick: Metabolism and tumor cell growth. Curr. Opin. Genet. Dev. 2008, 18, 54-61. [CrossRef] [PubMed]

67. Araki, K.; Ahmed, R. AMPK: A metabolic switch for CD8 ${ }^{+}$T-cell memory. Eur. J. Immunol. 2013, 43, 878-881. [CrossRef] [PubMed]

68. Araki, K.; Turner, A.P.; Shaffer, V.O.; Gangappa, S.; Keller, S.A.; Bachmann, M.F.; Larsen, C.P.; Ahmed, R. mTOR regulates memory CD8 T-cell differentiation. Nature 2009, 460, 108-112. [CrossRef] [PubMed]

69. Kidani, Y.; Elsaesser, H.; Hock, M.B.; Vergnes, L.; Williams, K.J.; Argus, J.P.; Marbois, B.N.; Komisopoulou, E.; Wilson, E.B.; Osborne, T.F.; et al. Sterol regulatory element-binding proteins are essential for the metabolic programming of effector T cells and adaptive immunity. Nat. Immunol. 2013, 14, 489-499. [CrossRef] [PubMed]

70. Kurebayashi, Y.; Nagai, S.; Ikejiri, A.; Ohtani, M.; Ichiyama, K.; Baba, Y.; Yamada, T.; Egami, S.; Hoshii, T.; Hirao, A.; et al. PI3K-Akt-mTORC1-S6K1/2 axis controls Th17 differentiation by regulating Gfi1 expression and nuclear translocation of RORgamma. Cell Rep. 2012, 1, 360-373. [CrossRef] [PubMed]

71. Yang, K.; Chi, H. mTOR and metabolic pathways in T cell quiescence and functional activation. Semin. Immunol. 2012, 24, 421-428. [CrossRef] [PubMed]

72. Wang, R.; Dillon, C.P.; Shi, L.Z.; Milasta, S.; Carter, R.; Finkelstein, D.; McCormick, L.L.; Fitzgerald, P.; Chi, H.; Munger, J.; et al. The transcription factor Myc controls metabolic reprogramming upon T lymphocyte activation. Immunity 2011, 35, 871-882. [CrossRef] [PubMed]

73. Shi, L.Z.; Wang, R.; Huang, G.; Vogel, P.; Neale, G.; Green, D.R.; Chi, H. HIF1alpha-dependent glycolytic pathway orchestrates a metabolic checkpoint for the differentiation of TH17 and Treg cells. J. Exp. Med. 2011, 208, 1367-1376. [CrossRef] [PubMed]

74. Battaglia, M.; Stabilini, A.; Migliavacca, B.; Horejs-Hoeck, J.; Kaupper, T.; Roncarolo, M.G. Rapamycin promotes expansion of functional $\mathrm{CD} 4^{+} \mathrm{CD} 25^{+} \mathrm{FOXP} 3^{+}$regulatory $\mathrm{T}$ cells of both healthy subjects and type 1 diabetic patients. J. Immunol. 2006, 177, 8338-8347. [CrossRef] [PubMed]

75. Zeng, H.; Yang, K.; Cloer, C.; Neale, G.; Vogel, P.; Chi, H. mTORC1 couples immune signals and metabolic programming to establish T(reg)-cell function. Nature 2013, 499, 485-490. [CrossRef] [PubMed]

76. Francisco, L.M.; Salinas, V.H.; Brown, K.E.; Vanguri, V.K.; Freeman, G.J.; Kuchroo, V.K.; Sharpe, A.H. PD-L1 regulates the development, maintenance, and function of induced regulatory T cells. J. Exp. Med. 2009, 206, 3015-3029. [CrossRef] [PubMed]

77. Keir, M.E.; Butte, M.J.; Freeman, G.J.; Sharpe, A.H. PD-1 and its ligands in tolerance and immunity. Annu. Rev. Immunol. 2008, 26, 677-704. [CrossRef] [PubMed]

78. Lastwika, K.J.; Wilson, W.; Li, Q.K.; Norris, J.; Xu, H.; Ghazarian, S.R.; Kitagawa, H.; Kawabata, S.; Taube, J.M.; Yao, S.; et al. Control of PD-L1 Expression by Oncogenic Activation of the AKT-mTOR Pathway in Non-Small Cell Lung Cancer. Cancer Res. 2016, 76, 227-238. [CrossRef] [PubMed] 
79. Qian, B.Z.; Pollard, J.W. Macrophage diversity enhances tumor progression and metastasis. Cell 2010, 141, 39-51. [CrossRef] [PubMed]

80. Mantovani, A.; Sozzani, S.; Locati, M.; Allavena, P.; Sica, A. Macrophage polarization: Tumor-associated macrophages as a paradigm for polarized M2 mononuclear phagocytes. Trends Immunol. 2002, 23, 549-555. [CrossRef]

81. Mercalli, A.; Calavita, I.; Dugnani, E.; Citro, A.; Cantarelli, E.; Nano, R.; Melzi, R.; Maffi, P.; Secchi, A.; Sordi, V.; et al. Rapamycin unbalances the polarization of human macrophages to M1. Immunology 2013, 140, 179-190. [CrossRef] [PubMed]

82. Shan, M.; Qin, J.; Jin, F.; Han, X.; Guan, H.; Li, X.; Zhang, J.; Zhang, H.; Wang, Y. Autophagy suppresses isoprenaline-induced M2 macrophage polarization via the ROS/ERK and mTOR signaling pathway. Free Radic. Biol. Med. 2017, 110, 432-443. [CrossRef] [PubMed]

83. Chen, W.; Ma, T.; Shen, X.N.; Xia, X.F.; Xu, G.D.; Bai, X.L.; Liang, T.B. Macrophage-induced tumor angiogenesis is regulated by the TSC2-mTOR pathway. Cancer Res. 2012, 72, 1363-1372. [CrossRef] [PubMed]

84. Hallowell, R.W.; Collins, S.L.; Craig, J.M.; Zhang, Y.; Oh, M.; Illei, P.B.; Chan-Li, Y.; Vigeland, C.L.; Mitzner, W.; Scott, A.L.; et al. mTORC2 signalling regulates M2 macrophage differentiation in response to helminth infection and adaptive thermogenesis. Nat. Commun. 2017, 8, 14208. [CrossRef] [PubMed]

85. Shrivastava, R.; Asif, M.; Singh, V.; Dubey, P.; Ahmad Malik, S.; Lone, M.U.; Tewari, B.N.; Baghel, K.S.; Pal, S.; Nagar, G.K.; et al. M2 polarization of macrophages by Oncostatin M in hypoxic tumor microenvironment is mediated by mTORC2 and promotes tumor growth and metastasis. Cytokine 2018. [CrossRef] [PubMed]

86. Welte, T.; Kim, I.S.; Tian, L.; Gao, X.; Wang, H.; Li, J.; Holdman, X.B.; Herschkowitz, J.I.; Pond, A.; Xie, G.; et al. Oncogenic mTOR signalling recruits myeloid-derived suppressor cells to promote tumour initiation. Nat. Cell Biol. 2016, 18, 632-644. [CrossRef] [PubMed]

87. Ryzhov, S.V.; Pickup, M.W.; Chytil, A.; Gorska, A.E.; Zhang, Q.; Owens, P.; Feoktistov, I.; Moses, H.L.; Novitskiy, S.V. Role of TGF-beta signaling in generation of CD39+CD73 ${ }^{+}$myeloid cells in tumors. J. Immunol. 2014, 193, 3155-3164. [CrossRef] [PubMed]

88. Raber, P.L.; Sierra, R.A.; Thevenot, P.T.; Shuzhong, Z.; Wyczechowska, D.D.; Kumai, T.; Celis, E.; Rodriguez, P.C. T cells conditioned with MDSC show an increased anti-tumor activity after adoptive T cell based immunotherapy. Oncotarget 2016, 7, 17565-17578. [CrossRef] [PubMed]

89. Hanahan, D.; Weinberg, R.A. Hallmarks of cancer: The next generation. Cell 2011, 144, 646-674. [CrossRef] [PubMed]

90. Hicklin, D.J.; Ellis, L.M. Role of the vascular endothelial growth factor pathway in tumor growth and angiogenesis. J. Clin. Oncol. 2005, 23, 1011-1027. [CrossRef] [PubMed]

91. Advani, S.H. Targeting mTOR pathway: A new concept in cancer therapy. Indian J. Med. Paediatr. Oncol. 2010, 31, 132-136. [CrossRef] [PubMed]

92. Semenza, G.L. Hydroxylation of HIF-1: Oxygen sensing at the molecular level. Physiology (Bethesda) 2004, 19, 176-182. [CrossRef] [PubMed]

93. Faes, S.; Santoro, T.; Demartines, N.; Dormond, O. Evolving Significance and Future Relevance of Anti-Angiogenic Activity of mTOR Inhibitors in Cancer Therapy. Cancers (Basel) 2017, 9, 152. [CrossRef] [PubMed]

94. Dodd, K.M.; Tee, A.R. STAT3 and mTOR: Co-operating to drive HIF and angiogenesis. Oncoscience 2015, 2 , 913-914. [PubMed]

95. DeYoung, M.P.; Horak, P.; Sofer, A.; Sgroi, D.; Ellisen, L.W. Hypoxia regulates TSC1/2-mTOR signaling and tumor suppression through REDD1-mediated 14-3-3 shuttling. Genes Dev. 2008, 22, 239-251. [CrossRef] [PubMed]

96. Gwinn, D.M.; Shackelford, D.B.; Egan, D.F.; Mihaylova, M.M.; Mery, A.; Vasquez, D.S.; Turk, B.E.; Shaw, R.J. AMPK phosphorylation of raptor mediates a metabolic checkpoint. Mol. Cell 2008, 30, 214-226. [CrossRef] [PubMed]

97. Squadrito, M.L.; De Palma, M. Macrophage regulation of tumor angiogenesis: Implications for cancer therapy. Mol. Aspects Med. 2011, 32, 123-145. [CrossRef] [PubMed]

98. Maity, A.; Pore, N.; Lee, J.; Solomon, D.; O'Rourke, D.M. Epidermal growth factor receptor transcriptionally up-regulates vascular endothelial growth factor expression in human glioblastoma cells via a pathway involving phosphatidylinositol 3'-kinase and distinct from that induced by hypoxia. Cancer Res. 2000, 60, 5879-5886. [PubMed] 
99. Pore, N.; Liu, S.; Haas-Kogan, D.A.; O’Rourke, D.M.; Maity, A. PTEN mutation and epidermal growth factor receptor activation regulate vascular endothelial growth factor (VEGF) mRNA expression in human glioblastoma cells by transactivating the proximal VEGF promoter. Cancer Res. 2003, 63, 236-241. [PubMed]

100. Zundel, W.; Schindler, C.; Haas-Kogan, D.; Koong, A.; Kaper, F.; Chen, E.; Gottschalk, A.R.; Ryan, H.E.; Johnson, R.S.; Jefferson, A.B.; et al. Loss of PTEN facilitates HIF-1-mediated gene expression. Genes Dev. 2000, 14, 391-396. [PubMed]

101. Fang, J.; Ding, M.; Yang, L.; Liu, L.Z.; Jiang, B.H. PI3K/PTEN/AKT signaling regulates prostate tumor angiogenesis. Cell Signal. 2007, 19, 2487-2497. [CrossRef] [PubMed]

102. Ma, X.M.; Blenis, J. Molecular mechanisms of mTOR-mediated translational control. Nat. Rev. Mol. Cell Biol. 2009, 10, 307-318. [CrossRef] [PubMed]

103. Orimo, A.; Gupta, P.B.; Sgroi, D.C.; Arenzana-Seisdedos, F.; Delaunay, T.; Naeem, R.; Carey, V.J.; Richardson, A.L.; Weinberg, R.A. Stromal fibroblasts present in invasive human breast carcinomas promote tumor growth and angiogenesis through elevated SDF-1/CXCL12 secretion. Cell 2005, 121, 335-348. [CrossRef] [PubMed]

104. Bhowmick, N.A.; Neilson, E.G.; Moses, H.L. Stromal fibroblasts in cancer initiation and progression. Nature 2004, 432, 332-337. [CrossRef] [PubMed]

105. Grum-Schwensen, B.; Klingelhofer, J.; Berg, C.H.; El-Naaman, C.; Grigorian, M.; Lukanidin, E.; Ambartsumian, N. Suppression of tumor development and metastasis formation in mice lacking the S100A4(mts1) gene. Cancer Res. 2005, 65, 3772-3780. [CrossRef] [PubMed]

106. Apte, M.V.; Pirola, R.C.; Wilson, J.S. Pancreatic stellate cells: A starring role in normal and diseased pancreas. Front. Physiol. 2012, 3, 344. [CrossRef] [PubMed]

107. Kumar, V.; Donthireddy, L.; Marvel, D.; Condamine, T.; Wang, F.; Lavilla-Alonso, S.; Hashimoto, A.; Vonteddu, P.; Behera, R.; Goins, M.A.; et al. Cancer-Associated Fibroblasts Neutralize the Anti-tumor Effect of CSF1 Receptor Blockade by Inducing PMN-MDSC Infiltration of Tumors. Cancer Cell 2017, 32, 654-668. [CrossRef] [PubMed]

108. Shan, T.; Chen, S.; Chen, X.; Lin, W.R.; Li, W.; Ma, J.; Wu, T.; Cui, X.; Ji, H.; Li, Y.; et al. Cancer-associated fibroblasts enhance pancreatic cancer cell invasion by remodeling the metabolic conversion mechanism. Oncol. Rep. 2017, 37, 1971-1979. [CrossRef] [PubMed]

109. Erkan, M. Understanding the stroma of pancreatic cancer: Co-evolution of the microenvironment with epithelial carcinogenesis. J. Pathol. 2013, 231, 4-7. [CrossRef] [PubMed]

110. Von Ahrens, D.; Bhagat, T.D.; Nagrath, D.; Maitra, A.; Verma, A. The role of stromal cancer-associated fibroblasts in pancreatic cancer. J. Hematol. Oncol. 2017, 10, 76. [CrossRef] [PubMed]

111. Kumari, N.; Dwarakanath, B.S.; Das, A.; Bhatt, A.N. Role of interleukin-6 in cancer progression and therapeutic resistance. Tumour Biol. 2016, 37, 11553-11572. [CrossRef] [PubMed]

112. Wang, Y.; Gan, G.; Wang, B.; Wu, J.; Cao, Y.; Zhu, D.; Xu, Y.; Wang, X.; Han, H.; Li, X.; et al. Cancer-associated Fibroblasts Promote Irradiated Cancer Cell Recovery Through Autophagy. EBioMedicine 2017, 17, 45-56. [CrossRef] [PubMed]

113. Chen, D.S.; Mellman, I. Elements of cancer immunity and the cancer-immune set point. Nature 2017, 541, 321-330. [CrossRef] [PubMed]

114. Bethune, M.T.; Joglekar, A.V. Personalized T cell-mediated cancer immunotherapy: Progress and challenges. Curr. Opin. Biotechnol. 2017, 48, 142-152. [CrossRef] [PubMed]

115. Pancione, M.; Giordano, G.; Parcesepe, P.; Cerulo, L.; Coppola, L.; Curatolo, A.D.; Conciatori, F.; Milella, M.; Porras, A. Emerging Insight into MAPK Inhibitors and Immunotherapy in Colorectal Cancer. Curr. Med. Chem. 2017, 24, 1383-1402. [CrossRef] [PubMed]

116. O'Donnell, J.S.; Massi, D.; Teng, M.W.L.; Mandala, M. PI3K-AKT-mTOR inhibition in cancer immunotherapy, redux. Semin. Cancer Biol. 2018, 48, 91-103. [CrossRef] [PubMed]

117. Saunders, R.N.; Metcalfe, M.S.; Nicholson, M.L. Rapamycin in transplantation: A review of the evidence. Kidney Int. 2001, 59, 3-16. [CrossRef] [PubMed]

118. Parsa, A.T.; Waldron, J.S.; Panner, A.; Crane, C.A.; Parney, I.F.; Barry, J.J.; Cachola, K.E.; Murray, J.C.; Tihan, T.; Jensen, M.C.; et al. Loss of tumor suppressor PTEN function increases B7-H1 expression and immunoresistance in glioma. Nat. Med. 2007, 13, 84-88. [CrossRef] [PubMed] 
119. George, S.; Miao, D.; Demetri, G.D.; Adeegbe, D.; Rodig, S.J.; Shukla, S.; Lipschitz, M.; Amin-Mansour, A.; Raut, C.P.; Carter, S.L.; et al. Loss of PTEN Is Associated with Resistance to Anti-PD-1 Checkpoint Blockade Therapy in Metastatic Uterine Leiomyosarcoma. Immunity 2017, 46, 197-204. [CrossRef] [PubMed]

120. Song, M.; Chen, D.; Lu, B.; Wang, C.; Zhang, J.; Huang, L.; Wang, X.; Timmons, C.L.; Hu, J.; Liu, B.; et al. PTEN loss increases PD-L1 protein expression and affects the correlation between PD-L1 expression and clinical parameters in colorectal cancer. PLoS ONE 2013, 8, e65821. [CrossRef] [PubMed]

121. Mittendorf, E.A.; Philips, A.V.; Meric-Bernstam, F.; Qiao, N.; Wu, Y.; Harrington, S.; Su, X.; Wang, Y.; Gonzalez-Angulo, A.M.; Akcakanat, A.; et al. PD-L1 expression in triple-negative breast cancer. Cancer Immunol. Res. 2014, 2, 361-370. [CrossRef] [PubMed]

122. Zhao, L.; Li, C.; Liu, F.; Zhao, Y.; Liu, J.; Hua, Y.; Liu, J.; Huang, J.; Ge, C. A blockade of PD-L1 produced antitumor and antimetastatic effects in an orthotopic mouse pancreatic cancer model via the PI3K/Akt/mTOR signaling pathway. Onco Targets Ther. 2017, 10, 2115-2126. [CrossRef] [PubMed]

123. Chapman, N.M.; Chi, H. mTOR signaling, Tregs and immune modulation. Immunotherapy 2014, 6, 1295-1311. [CrossRef] [PubMed]

124. Huijts, C.M.; Santegoets, S.J.; Quiles Del Rey, M.; de Haas, R.R.; Verheul, H.M.; de Gruijl, T.D.; van der Vliet, H.J. Differential effects of inhibitors of the PI3K/mTOR pathway on the expansion and functionality of regulatory T cells. Clin. Immunol. 2016, 168, 47-54. [CrossRef] [PubMed]

125. Marshall, N.A.; Galvin, K.C.; Corcoran, A.M.; Boon, L.; Higgs, R.; Mills, K.H. Immunotherapy with PI3K inhibitor and Toll-like receptor agonist induces IFN-gamma+IL-17+ polyfunctional T cells that mediate rejection of murine tumors. Cancer Res. 2012, 72, 581-591. [CrossRef] [PubMed]

(C) 2018 by the authors. Licensee MDPI, Basel, Switzerland. This article is an open access article distributed under the terms and conditions of the Creative Commons Attribution (CC BY) license (http:/ / creativecommons.org/licenses/by/4.0/). 